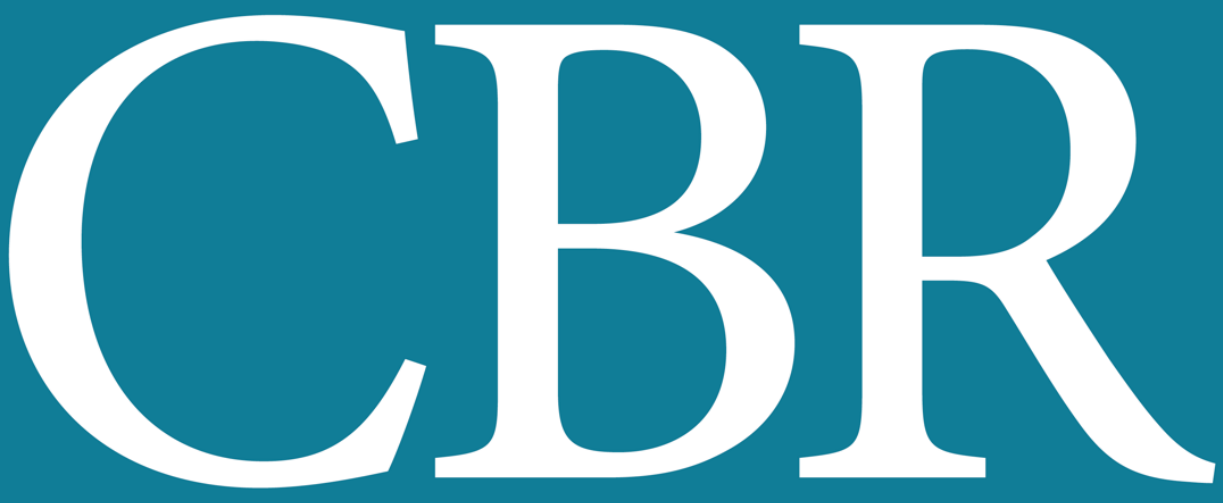

INTERNATIONAL JOURNAL OF CANCER AND BIOMEDICAL RESEARCH

https://jcbr.journals.ekb.eg

Editor-in-chief

Prof. Mohamed Labib Salem, PhD

Phoenix dactyliferaseed extract ameliorates the biochemical toxicity induced by silver nanoparticles in mice

Sabry A. El-Naggar, El-Sayyedah Kh. T. Ayyad, Ramadan M.

Kandyel and Mohamed L. Salem 


\title{
Phoenix dactylifera seed extract ameliorates the biochemical toxicity induced by silver nanoparticles in mice
}

\author{
Sabry A. El-Naggar, El-Sayyedah Kh. T. Ayyad, Ramadan M. Kandyel and Mohamed L. Salem \\ Zoology Department, Faculty of Science, Tanta University, Tanta, Egypt
}

\section{III}

\section{ABSTRACT}

Background: Recently, silver nanoparticles (AgNPs) are involved in several biomedical, industrial and agriculture applications. However, the accumulation of these particles in the human body causes severe side effects on different vital organs. Phoenix dactylifera seed extract (PDSE) showed a biological activity as a hepatic-renal protective agent. Aim: This study was conducted to evaluate the hepatic-protective effect of the PDSE on AgNPs induced toxicity in mice. Materials and methods: Forty male mice were divided into 4 groups $(n=10)$ as follows: $G p 1$ was injected intraperitoneally (i.p) with $200 \mu$ sterile saline. Gp2 was injected i.p with PDSE $(100 \mathrm{mg} / \mathrm{kg})$ for a month. Gp3 was injected i.p with AgNPs $(0.25 \mu \mathrm{l})$ for one month and Gp4 was injected with AgNPs as in Gp3 then injected with PDSE as in Gp2. Some hematological and biochemical parameters were determined with histological observation. Results: The results showed that injection of AgNPs led to toxicity in both liver and kidney organs as shown by elevation of liver enzymes aspartate transaminase, alanine transaminase, and kidney enzymes: urea and creatinine levels. Furthermore, the activity of antioxidant enzymes superoxide dismutase and catalase was decreased, while the level of malondialdehyde increased. Histologically, AgNPs injection altered the architectures of the liver and kidney tissues. Treatment with PDSE post-AgNPs injection ameliorated all previous parameters induced by AgNPs toxicity. Conclusion: PDSE has the potential to augment the pathophysiological alternation in the liver induced by AgNPs toxicity in mice.

Keywords: Antioxidants enzymes, nanoparticles; phoenix dactylifera; silver; Toxicity

\section{ARTICLE INFO}

Article history
Received: July 4, 2021
Revised: August 14, 2021
Accepted: August 18, 2021
Correspondence to
El-Sayyedah Kh. T. Ayyad, M.Sc
Zoology Department,
Faculty of Science,
Tanta University, Tanta, Egypt
Mobile: (+2) 01005739066
Email:
khadijahtawfiqayyad@gmail.com
Copyright
( 2021 Sabry El-Naggar, El-Sayyedah
Ayyad, Ramadan Kandyel, Mohamed
Salem. This is an Open Access article
distributed under the Creative
Commons Attribution License, which
permits unrestricted use, distribution,
and reproduction in any medium,
provided the original work is properly
cited.

Editor-in-Chief: Prof. M.L. Salem, PhD - Article DOI: 10.21608/jcbr.2021.83942.1217

\section{INTRODUCTION}

Nanotechnology is a rapidly growing field of interdisciplinary research, particularly in biotechnology (Natarajan et al., 2010). Nanoparticles (NPs) are particles with an average size range between 1-100 $\mathrm{nm}$ (Ema et al., 2017). The application of nanomaterials ranges from the novel domain of drug targeting to the creation of infection-resistant surfaces. Silver nanoparticles (AgNPs) are generally used in preclinical trials and clinical settings for the treatment of different diseases (Natarajan et al., 2010; Chen et al., 2013). Although the use of AgNPs is steadily increasing in biomedical applications, little is known regarding the potential health hazards, of food supplements, plastic food containers, coatings on medical devices, water disinfectants, air filters, electronic gadgets, odor-resistant textile fabrics and cosmetics items such as deodorants, which all contain AgNPs (Quang et al., 2013; Vance et al., 2015). AgNPs have recently been identified as ideal candidates for conquering pathologies previously treated with conventional antibiotics (Zhu et al., 2014). AgNPs are used as antibacterial, antifungal, antiviral, and antiinflammatory agents (El-Badawy et al., 2010).

Herbal medicine is the study of pharmacognosy and the application of medicinal herbs, which forms the foundation of traditional medicine (Lack et al., 2016). People with chronic diseases like cancer, diabetes, asthma and end-stage kidney disease are more likely to take herbal medicines (Roozbeh et al., 2013). Herbs are now used to treat chronic and acute illnesses, as well as a variety of maladies and difficulties such 
as cardiovascular disease, prostate issues, depression and inflammation, as well as to enhance the immune system. Herbal medications are increasing in popularity and researchers are currently investigating the scientific basis for their medicinal effects (Gupta and Briyal, 2004). Medicinal plants that contain phytochemicals like polyphenolic compounds can help to prevent degenerative diseases such as cancer, cardiovascular disease and neurological illnesses (Tsao, 2010). Polyphenols are powerful antioxidants that work in tandem with antioxidant vitamins and enzymes to protect the body from oxidative stress caused by the increased production of reactive oxygen species (Dong et al., 2009).

Phoenix dactylifera $L$, also known as date or date palm, is a flowering plant in the Arecaceae palm family that is grown for its tasty sweet fruit. The species is commonly farmed in Northern Africa, the Middle East and South Asia, as well as in many tropical and subtropical climates around the world. $P$. dactylifera $L$ is the type species of the genus Phoenix, which includes 12-19 species of wild date palms and is the most important commercial source of production (Krueger and Robert, 2018). The $P$. dactylifera $L$. is a centuries-old native of the Middle East (Adaay and Mattar, 2012). Many pharmacological investigations have been conducted due to a growing interest in the numerous health-promoting characteristics of date fruits and seeds (Chao and Krueger, 2007). $P$. dactylifera $L$ is a good source of dietary potassium and include a wide spectrum of vital elements and offer a good promise in the treatment of diabetes due to the presence of polyphenols that have strong antioxidant properties (Mia, 2020).

Several pure aqueous and combined aqueous/organic solvent extracts of date palm fruits were discovered to have oxidative stress activity, free radical scavenging capability, coronary heart disease prevention, hepatic protective, anti-inflammatory and anticancer activities against prostate cancer cells (Mirza et al., 2018). Date fruit shows potential health advantages against a variety of cancers. $P$. dactylifera $L$ consumption lowered the incidence rate of breast cancer, palpable tumour multiplicity, tumour size, and weight
(Al-Sayyed et al., 2014). By promoting the growth of good bacteria and reducing the multiplication of colon cancer cells, $P$. dactylifera $L$ may help to improve colon health (Eid et al., 2014). The present study aims to address the potential protective effect of Phoenix dactylifera $L$. seeds extract (PDSE) on the liver of mice exposed to silver nanoparticles.

\section{MATERIALS AND METHODS}

\section{Chemicals \\ Silver nanoparticles (AgNPs)}

Silver nanoparticles (AgNPs) with average size $(15 \pm 3 \mathrm{~nm})$ were purchased from Nanotech Egypt for Photo-Electronics (El-Wahaat Road, Dream Land City, Entrance 3, City of 6 October, Giza, Egypt. Vials were diluted by phosphate buffer saline (PBS) and the concentration was adjusted to $0.25 \mathrm{mg} / \mathrm{kg}$, in $200 \mu \mathrm{l}$ (Hemen Moradi-Sardareha et al., 2018). Aspartate amino transferase (AST), alanine aminotransferase (ALT), urea, creatinine, albumin, total protein, superoxide dismutase (SOD), catalase (CAT), reduced glutathione (GSH) and malondialdehyde (MDA) kits were purchased from Bio diagnostic company, Egypt.

\section{Phoenix dactylifera $L$. seeds and extracts preparation}

Phoenix dactylifera $L$. was purchased from a local market in Tanta city, Egypt. The plant materials were identified and authenticated by a taxonomist at the Botany Department, Faculty of Science, Tanta University. Phoenix dactylifera $L$. seeds were dried in shade then crushed in a mortar and the powder was kept in a suitable place for further studies. $50 \mathrm{~g}$ of seed powder was mixed vigorously with $500 \mathrm{~mL} 70 \%$ (V/V) ethanol. The hydro-alcoholic extracts were filtered and the solvent was dried under air condition, then the extracts were weighed and suspended in $0.9 \%$ sterile saline for further processing.

\section{Animals}

Forty male Swiss albino mice (20 $\pm 2 \mathrm{~g}$ ) were allowed acclimating for a week in the animal facility conditions at the Faculty of Science, Tanta University, before experimentation. The institutional animal care committee and Local Ethics Committee and Animals Research (Faculty of Science, Tanta University- Egypt), 
approved the experimental design and protocol (IACUC-SCI-TU- 0187).

\section{Experimental design}

The laboratory confions used used were about $22 \pm 1 \stackrel{\circ}{ } \mathrm{C}, 55 \pm 5 \% \mathrm{RH}$, and 12:12h (day/night) cycle. Mice were supplied with drinking tap water and normal experimental pelleted animal food ad libitium. After 1 week of acclimation period in the animal facility, mice were divided into four groups ( $n=10)$. Gp 1 mice were injected intraperitoneal (i.p) with saline for one month); Gp 2 were injected i.p with PDSE $(100 \mathrm{mg} / \mathrm{kg})(\mathrm{El}-$ Habibi, et al., 2017) for a month; Gp 3 were injected i.p with AgNPs (0.25 $\mu$ l) for one month and Gp 4 were injected with AgNPs as in Gp3 then injected with PDSE as in Gp2. Mice were sacrificed to collect blood samples for hematological, biochemical and histological investigation.

\section{Hematology and biochemical analysis}

Complete blood pictures (CBC) were determined in all the studied groups using automatic methods (Sysmex kx-21n automated hematology analyzer; JAPAN CARE CO., LTD) (Fujimoto, 1999), which include red blood cells (RBCs), hemoglobin $(\mathrm{Hb})$, hematocrit value $(\mathrm{Hct})$, leucocyte count and platelets (Plt) (ElMoghazy et al.,2014). Liver enzymatic levels such as aspartate transaminase (AST), alanine transaminase (ALT), alkaline phosphatase (ALP), Albumin levels and serum total protein levels were determined (Moss et al.,1999; Schumann and Klauke, 2003). Catalase (CAT), superoxide dismutase (SOD), Malondialdehyde (MDA), and glutathione (GSH) were assayed according to earlier methods (Aebi, 1984; Nishikimi et al., 1972; Buege and Aust, 1978; Beutler et al., 1963).

\section{Histopathological investigations}

Histopathological investigations, small parts from livers were preserved in $10 \%$ phosphatebuffered formalin at 4-5 $\mathrm{mm}^{3}$ thickness, dehydrated in graded alcohol series, cleared in xylene and embedded in paraffin blocks. 4-5 $\mu \mathrm{m}$ sections of the collected sections were stained with heamatoxylin and eosin for histopathological examination (Bancroft and Stevens, 1996).

\section{Statistical Analysis}

The data were expressed as mean \pm SD. Comparison between groups was carried out using one-way ANOVA. If there is a significant difference between means, Tukey post-hoc comparisons among different groups were performed. For all statistical tests, $\mathrm{P}<0.05$ was considered to be statistically significant. Data and statistical analysis were performed using Excel 2013 (Microsoft Corporation, USA), and Minitab (version 18).

\section{RESULTS}

Bodyweight changes upon the injection with AgNPs and treatment with PDSE

The initial body weight of different groups was approximately $20 \pm 2$ g. Post a month of treatment either with AgNPs (Gp3), PDSE alone (Gp2) or with a combination of AgNPs/PDSE (Gp4), the final body weight of mice were found more or less similar (Figure 1). The Group of mice that were treated with AgNPs alone (Gp3) showed a decrease in the final body weight as compared with Gp1 or the group injected with PDSE alone (Gp2). The treatment with AgNPs/PDSE (Gp4) did not enhance ( $P \geq 0.05$ ) the final body weight of treated mice with AgNPs and was still lower $(P<0.05)$ than those in the control.

\section{PDSE treatment post-AgNPs restored $\mathrm{CBC}$ close to normal value}

The results showed that the total number of red blood cell (RBCs), hemoglobin ( $\mathrm{Hb}$ ) content and hematocrit (Hct) values did not change significantly $(P \geq 0.05)$ in the group of mice that were injected with PDSE when compared to the control group (Gp1). Significant decreases $(P<$ 0.05 ) in the previous parameters were reported in mice that were treated with AgNPs. The total number of white blood cells (WBCs) did not change significantly $(P \geq 0.05)$ in the group of mice that were injected with PDSE but this count showed an increase in the group of mice that were treated with AgNPs. Mice treated with PDSE post-AgNPs injection restored the count of WBCs close to normal. The platelets number was significantly increased $(P<0.05)$ in the treatment of mice with AgNPs only as compared to the control group (Table 1). 


\section{PDSE treatment post-AgNPs injection enhanced the liver function}

The results showed that the liver enzymes (ALT, AST and ALP) increased in the group of mice that were injected with AgNPs when compared to control mice. Treatment of mice with PDSE post-AgNPs injection restored ALT, AST and ALP levels close to normal range (Table 2). The results showed that the total protein and albumin levels significantly $(P<0.05)$ decreased in the mice that were injected with AgNPs when compared to their values in control mice. The mice that were injected with PDSE did not show any significant $(P \geq 0.05)$ in liver enzymes levels. Treatment of mice with PDSE post-AgNPs injection restored the total protein and albumin levels close to the normal range (Figure 2).

\section{Antioxidant effect of PDSE treatment post- AgNPs injection enhanced the enzymes}

The results showed that the level of SOD, CAT and GSH was decreased in the group of mice that were injected with AgNPs when compared to their value of control mice. Treatment with PDSE post-AgNPs injection restored the level of SOD, CAT and GSH close to normal range. Significance $(P<0.05)$ increased in MDA level in the group of mice that were injected with AgNPs; however, treatment of mice with PDSE post-AgNPs injection restored MDA level close to normal range (Figure 3 ).

\section{PDSE treatment post-AgNPs injection improved the liver architectures in AgNPs induced toxicity mice}

Histological observation of liver from mice exposed to AgNPs confirms the toxicity exerted by AgNPs. The liver section of mice injected with PDSE (Gp2) showed that the hepatic tissue had the same architecture as the control group except for the presence of few cytoplasmic vacuolations and few hepatocytes with deeply stained shrunken nuclei. The changes in the liver of the AgNPs treated mice (Gp3) showed disorganized hepatic strands with certain degenerative features. Most hepatic cells have rounded pyknotic darkly stained nuclei. The central veins showed atrophic changes including epithelial shedding and loss of their regular shape. Obvious cytoplasmic vacuolations which gave a spongy appearance, sinusoidal dilatation, swollen central vein, and dispersed congested dilated blood vessels were also noticed. Moreover, severe inflammatory cell infiltration was observed around the central vein area. Mice treated with PDSE post-AgNPs injection (Gp4), the light microscopic observations revealed marked improvement in hepatic cellularity. Hepatocytes had retained their regular shape with their basophilic cytoplasm and large centric rounded nuclei as compared to the AgNPs group (Gp3). Few hepatic cells showed darkly stained pyknotic nuclei, congested blood vessels, cytoplasmic vacuolations, and cell infiltration were also observed (Figure 4).

\section{DISCUSSION}

Silver nanoparticles (AgNPs) have the potential to be used in biosensing, imaging, cosmetics, medicine, home-products and research facilities, due to their unique physicochemical features (Dubas and Pimpan, 2008). The toxicity of AgNPs to human cells appears to be induced by oxidative stress and inflammation (AshaRani et al., 2009; Park et al., 2010; Gopinath et al., 2010; Wise et al., 2010). Phoenix dactylifera $L$. is a useful traditional medicinal plant. Its phytochemical investigation has revealed that the fruits contain anthocyanins, phenolics, sterols, carotenoids, procyanidins, and flavonoids, compounds known to possess free radical scavenging, anti-oxidant, antimutagenic, anti-microbial, anti-inflammatory, anti-hyperlipidemic, gastroprotective, hepatoprotective, nephroprotective, anticancer, and immunostimulant activities (Baliga et al., 2011; El-Far et al., 2016).

The current study was undertaken to investigate the therapeutic effect of PDSE against AgNPs induced toxicity in adult male mice. The results showed that there is a significant decrease in the bodyweight of mice injected with AgNPs when compared with the control group injected with saline. A similar study showed that exposure to AgNPs can lead to weight loss (Tiwari et al., 2011; Zhang et al., 2013; Xia et al., 2014). The present study revealed a significant decrease in the total number of RBCs, $\mathrm{Hb}$ level and Hct in AgNPs injection mice when compared with the control group which may reflect toxic effect of AgNPs 
Table 1. Effect of AgNPs on complete blood picture of different groups under study.

\begin{tabular}{|c|c|c|c|c|c|}
\hline Groups & $\begin{array}{c}\text { RBCs } \\
\left(\mathbf{x} 10^{6} / \mu \mathrm{L}\right)\end{array}$ & $\begin{array}{c}\text { Hb } \\
(\mathbf{g} / \mathbf{d L})\end{array}$ & $\begin{array}{c}\text { HCT } \\
(\%)\end{array}$ & $\begin{array}{c}\text { Plat. } \\
\left(\times 10^{3} / \mu \mathrm{L}\right)\end{array}$ & $\begin{array}{c}\text { WBCs } \\
\left(\mathbf{x 1 0 ^ { 3 }} / \boldsymbol{\mu L}\right)\end{array}$ \\
\hline Control & $7.5 \pm 0.14^{\mathrm{a}}$ & $13.5 \pm 0.50^{\mathrm{a}}$ & $37.4 \pm 0.93^{\mathrm{a}}$ & $465 \pm 1.08^{\mathrm{d}}$ & $4.79 \pm 0.26^{\mathrm{b}}$ \\
\hline PDSE & $7.7 \pm 0.16^{\mathrm{a}}$ & $13.3 \pm 0.26^{\mathrm{a}}$ & $33.4 \pm 1.00^{\mathrm{b}}$ & $757 \pm 2.08^{\mathrm{b}}$ & $4.97 \pm 0.59^{\mathrm{b}}$ \\
\hline AgNPs & $5.4 \pm 0.35^{\mathrm{b}}$ & $9.20 \pm 0.45^{\mathrm{b}}$ & $30.2 \pm 1.18^{\mathrm{c}}$ & $971 \pm 2.52^{\mathrm{a}}$ & $8.18 \pm 0.68^{\mathrm{a}}$ \\
\hline AgNPs/PDSE & $7.7 \pm 0.14^{\mathrm{a}}$ & $12.4 \pm 0.62^{\mathrm{a}}$ & $37.9 \pm 0.74^{\mathrm{a}}$ & $481 \pm 1.53^{\mathrm{c}}$ & $5.31 \pm 0.28^{\mathrm{b}}$ \\
\hline P value (one-way ANOVA) & 0.17 & 0.02 & 0.08 & 0.13 & 0.15 \\
\hline
\end{tabular}

Data are mean \pm SD of 3 replicates. PDSE Phoenix dactylifera seed extract; AgNPs silver nanoparticles; RBCs red blood cells; Hb hemoglobin; HCT hematocrit; Plat platelets; WBCs white blood cells. $P$-value $<0.05$ was considered to be statistically significant. The means that do not share the same letter are significantly different.

Table 2. Effect of AgNPs on Alanine transaminase (ALT), aspartate transaminase (AST) and alkaline phosphatase (ALP) level of different groups under study.

\begin{tabular}{|c|c|c|c|}
\hline Groups & ALT (U/L) & AST (U/L) & ALP (U/L) \\
\hline Control & $66.00 \pm 1.00^{\mathrm{d}}$ & $280.6 \pm 2.08^{\mathrm{b}}$ & $295 \pm 1.53^{\mathrm{b}}$ \\
\hline PDSE & $75.17 \pm 1.76^{\mathrm{c}}$ & $247.6 \pm 1.53^{\mathrm{c}}$ & $287 \pm 2.08^{\mathrm{c}}$ \\
\hline AgNPs & $119.0 \pm 2.00^{\mathrm{a}}$ & $399.3 \pm 1.5^{\mathrm{a}}$ & $379 \pm 2.65^{\mathrm{a}}$ \\
\hline AgNPs/PDSE & $99.00 \pm 1.52^{\mathrm{b}}$ & $277.0 \pm 2.0^{\mathrm{b}}$ & $285 \pm 2.00^{\mathrm{c}}$ \\
\hline P value (one-way ANOVA) & 0.001 & $<0.001$ & $<0.001$ \\
\hline
\end{tabular}

All data are the means of 3 replicates. The values represented mean \pm SD; PDSE Phoenix dactylifera seed extract; AgNPs silver nanoparticles; ALT alanine transaminase; AST aspartate transaminase; ALP alkaline phosphatase. $P$-value $<0.05$ was considered to be statistically significant. Means that do not share a letter are significantly different.

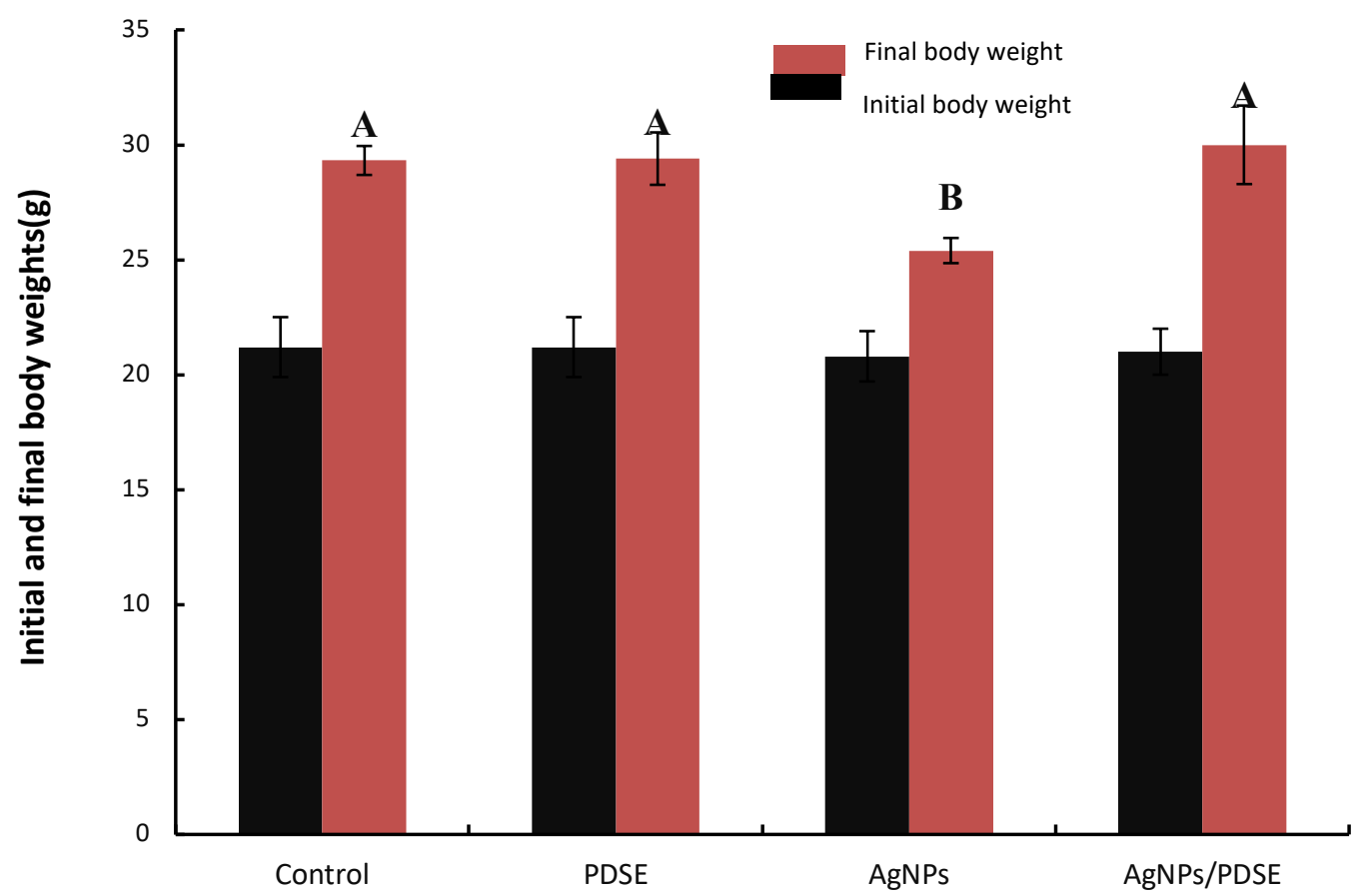

Figure 1. Initial and final body weight of different groups under study. Data was reported as mean $\pm S D$ of five animals in each group. Comparison among groups was done using one-way ANOVA. $P$-value $<0.05$ was considered to be statistically significant. Means that do not share a letter are significantly different. 

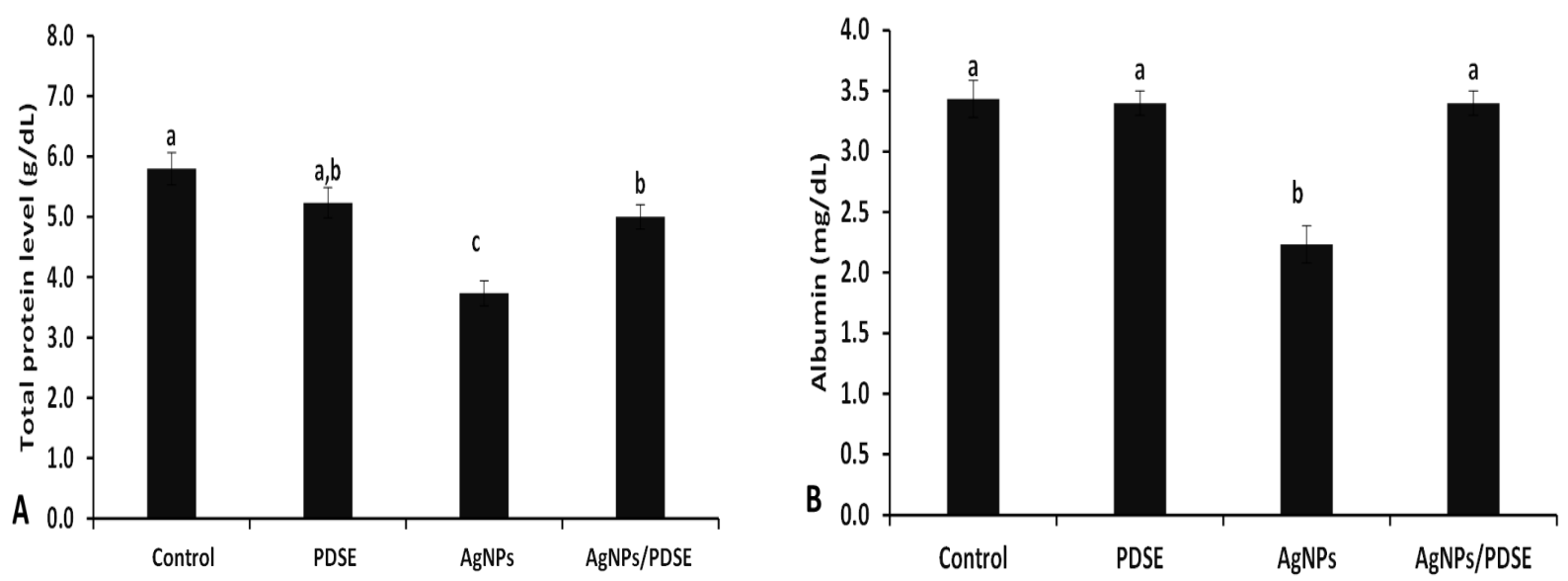

Figure 2. The influence of Phoenix dactylifera seed extract (PDSE), silver nanoparticles (AgNPs), and Phoenix dactylifera seed extract (PDSE), silver nanoparticles in combination on levels of total protein and albumin. Data was reported as mean $\pm S D$ of five animals in each group. Comparison among groups was done using one-way ANOVA. $P$-value $<0.05$ was considered to be statistically significant. Means that do not share a letter are significantly different.
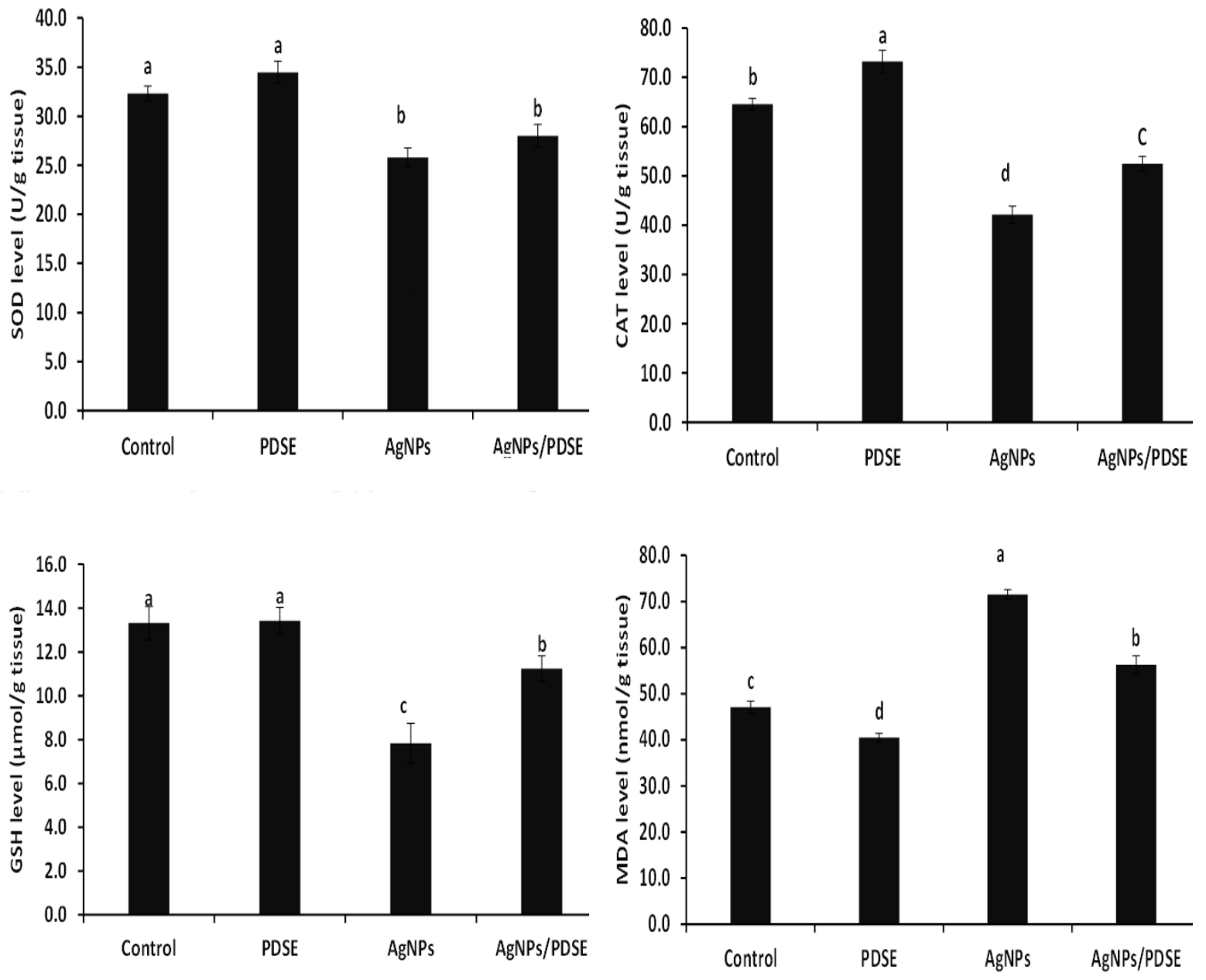

Figure 3. Effects of Phoenix dactylifera seed extract (PDSE), silver nanoparticles (AgNPs), and Phoenix dactylifera seed extract (PDSE), silver nanoparticles in combination on the activity of SOD, CAT, GSH and MDA in mice liver. Data was reported as mean $\pm S D$ of five animals in each group. Comparison among groups was done using oneway ANOVA. $P$-value $<0.05$ was considered to be statistically significant. Means that do not share a letter are significantly different. 

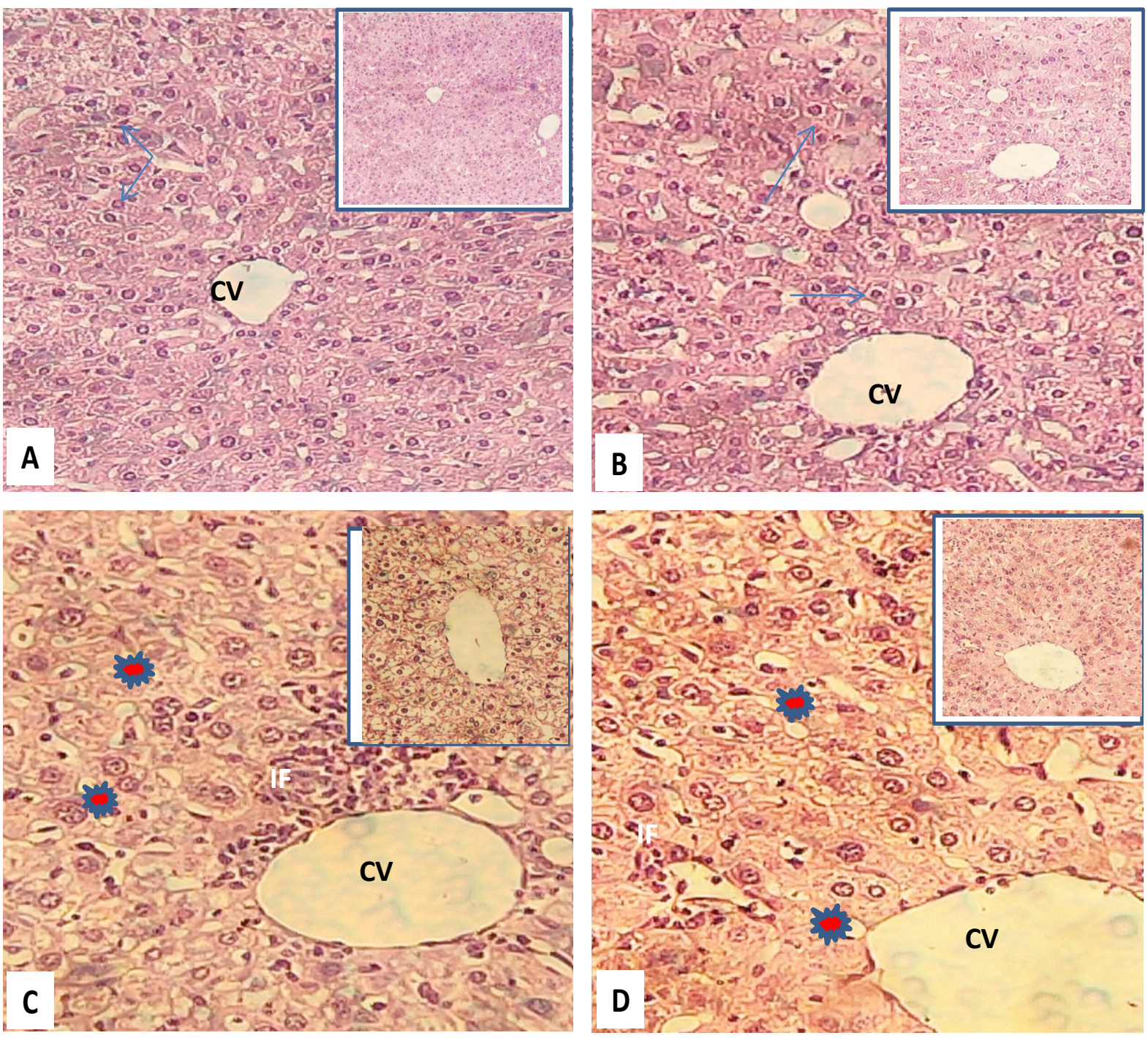

Figure 4. (A) Histological section of control liver tissue showing the normal structure of the liver, central vein (CV), hepatocytes (arrow). (B) Histological section of liver tissue of PDSE mice showing normal hepatic structure. (C) Histological section of liver tissue of AgNPs mice showing irregular shape of central vein (CV), inflammatory cells (IF), apoptotic hepatocytes (arrow). (D) Histological section of liver tissue of AgNPs mice treated with PDSE showing regular hepatocytes shape cytoplasmic vacuolations (red star) and cell infiltration (IF) (H\&E stain) (X100 - X400).

on bone marrow erythropoiesis. This finding was in agreement with Culling et al. (1985) who reported these alterations in RBCs may indicate effect of the Ag NPs on $\mathrm{Hb}$ syntheses during RBCs maturation during formation in bone marrow. Mice treated with PDSE post-AgNPs injection showed an improvement and increase in the total number of $\mathrm{RBC}, \mathrm{Hb}$ level and $\mathrm{Hct}$ values compared with control mice. This could be due to PDSE contain high vitamins and iron levels, which have been shown to promote RBCs proliferation and $\mathrm{Hb}$ oxygen-carrying function, which accounts for the better effects of diabetic treatment (Afolayan and Yakubu, 2009; Okonkwo et al., 2015). Treatment of AgNPs injected mice with PDSE significantly restored the hematological parameters to reach their normal values.

Therefore, the present finding indicates that PDSE might be able to induce a protective effect on the hematopoietic system. The present study revealed a significant increase in the total number of WBCs post-AgNPs when compared to the control group. In PDSE treated group post-AgNPs injection showed an improvement and decrease in the total number of WBC. WBCs play a crucial part in the body's immune response, serving as the first line of defence. AgNPs caused changes in the number of WBCs 
(Jun et al., 2011). The essential factors for AgNPs-induced morphological changes were discovered to be lymphocyte, macrophage infiltration, despite cell degeneration, regeneration, and necrosis (Chuang et al., 2013; Yun et al., 2015). Furthermore, mice were injected with AgNPs showed an increase in the total number of platelets compared with the control group. A previous study showed that platelets were aggregate and elevate coagulation activity by AgNPs injected mice (Kim et al., 2008; Martínez-Gutierrez et al., 2012). There is a significant increase in the levels of ALT, AST and ALP in the group of mice that were injected with AgNPs. These results may be attributed to the toxic effect of AgNPs on mice bodies that can be able to influence liver functions.

According to Park et al. (2010), hepatic damage induced by intraperitoneal injection of AgNPs in mice has possibly caused severe irritation of the oxidant system in these cells. Free radicals from AgNPs attacked hepatocytes, releasing ALT contained in them and allowing it to enter the blood serum; conversely, mice's immune reaction to an external stimulus was an increase in the number of WBCs for AgNPs phagocytosis (Braydich-Stolle et al., 2005).Treatment with PDSE post-AgNPs injection, showed a significant decrease in ALT, AST and ALP levels close to the normal range. This reduction could be due to the regeneration of hepatocytes and a possible healing effect on the hepatic parenchyma (Chatterjee et al., 2011). Ansar et al. (2017) reported that the increase in AST and ALT activities after intraperitoneal administration of AgNPs in male Wistar rats. This study showed that the total protein and albumin levels were significantly decreased in the mice that were injected with AgNPs when compared to their values in control mice. Cellular uptake of different AgNPs is found to be modulated by their interactions with different components of blood, including albumin, transferrin, and IgG (Monteiro-Riviere et al., 2013). The levels of rat serum and tissue total protein were altered as a result of the AgNPs.

Furthermore, treatment of mice with PDSE post-AgNPs injection restored the total protein and albumin levels close to the normal range. The activities of the antioxidant enzymes superoxide dismutase (SOD) and catalase (CAT) as well as glutathione (GSH) in the liver tissues was significantly reduced in the liver of AgNPs injected mice when compared to the control group.

These results showed that the serum level of SOD, CAT and GSH significantly reduced, which is consistent with the results of Ansar et al. (2017). Similar studies reported that AgNPs were decreased CAT activity and increased MDA levels in the liver of fish and rats which resulted in oxidative damage of the liver (Zhou et al., 2013; Adeyemi and Adewumi, 2014). Treatment with PDSE post-AgNPs injection restored the SOD, CAT and GSH level close to normal range. A previous study showed that Ajwa dated extract has a tissue-protective effect via free radical scavenging and antioxidant properties (Ragab et al., 2013). By contrast, there was a significant increase in the level of MDA in the mice that were injected with AgNPs. AgNPs enhanced production of MDA in hepatocyte may indicate oxidative stress (Xin et al., 2014). This result was in agreement with some other researches reported increased serum and tissue levels of MDA after AgNPs administration in rats and mice in comparison to the control non treated group (Adeyemi and Faniyan, 2014; Moradi-Sardareh et al., 2018).

Treatment of mice with PDSE post-AgNPs injection restored the MDA level close to the normal range. Additionally, the decreased MDA level associated with elevated other antioxidants in PDSE mice group may be attributed also to the wide range of phenolic compounds in that extract including $p$ coumaric, ferulic and sinapic acids, flavonoids and procyanidins (Al-Farsi et al., 2005). Meanwhile, treatment with PDSE to AgNPs group significantly increased the antioxidant levels SOD, CAT and GSH and decreasing MDA close to the normal rate. These might be reflecting the therapeutic effect of PDSE against AgNPs toxic effect. The protective effect of PDSE may be related to the accelerated activities of antioxidant enzymes such as CAT, SOD, GR, GST along with a significant reduction in MDA (EI-Far et al., 2016; Al-Yahya et al., 2016; Hoseinifar et al., 2017; Sharifi et al., 2017). 
The histological damages to the liver, kidney, skin, lung, cardiovascular system and reproductive organs have been proved in mammals exposed to AgNPs (Tang et al., 2009; Ahamed et al., 2010; Ema et al., 2017). Several studies have demonstrated that AgNPs exhibit hepatotoxicity effects in various both in vivo and in vitro models (Hussain et al., 2005: Gaiser et al., 2013). In the liver, however, most of the silver is deposited in Kupffer cells and hepatocytes (Buzea et al., 2007). Kupffer cells belong to the reticuloendothelial system and are responsible for AgNPs removal from the bloodstream (Kim et al., 2008). Hepatotoxic effects of AgNPs after entering into the cytoplasm and nuclei of the hepatocytes have been demonstrated in both in vivo and in vitro studies (Kim et al., 2008; Sung et al., 2009; Park et al., 2010; Kim et al., 2010; Gaiser et al., 2013). On the other hand, treatment with PDSE revealed marked improvement in hepatic cellularity. Hepatocytes had retained their regular shape with their basophilic cytoplasm and large centric rounded nuclei and some hepatic cells showed darkly stained pyknotic nuclei, congested blood vessels, cytoplasmic vacuolations, and cell infiltration. In another study, investigated. it can restore the altered hematological parameters, regulate liver function, modulated serum marker levels, antioxidant level and also improve histological alterations in liver tissues.

\section{CONFLICT OF INTEREST}

All authors declare no conflicts of interest.

\section{FUNDING}

No fund was received for this work.

\section{AUTHORS' CONTRIBUTION}

Not applicable.

\section{REFERENCES}

Adaay MH, Mattar AG. (2012). Effect of aqueous and ethanolic extracts of Tribulus terrestris, Phoenix dactylifera and Nasturtium officinale mixture on some reproductive parameters in male mice. Journal of Baghdad Sciences, 9(4): 640-650.

Adeyemi OS, Faniyan TO. (2014). Antioxidant status of rats administered silver nanoparticles orally. Journal of Taibah University Medical Sciences, 9 (3): 182-186.
Adeyemi OS, Akanji MA, Ekanem J.T. (2012). Ethanolic extract of Psidium guajava influences protein and bilirubin levels in Trypanosoma brucei brucei infected rats Journal Biol Sciences, $12: 111-116$

Afolayan AJ, Yakubu MT. (2009). Effect of Bulbinenatalensis Baker stem extract on the functional indices and histology of the liver and kidney of male Wistar rats. Journal of Medicinal Food, 12: 814-820.

Ahamed M, Alsalhi MS, Siddiqui MK (2010). "Silver nanoparticle applications and human health". Clinica Chimica Acta; International Journal of Clinical Chemistry.411(23-24): 1841-8.

Al-Farsi M, Alasalvar C, Morris A, Baron M, Shahidi F. (2005). Comparison of antioxidant activity, anthocyanins, carotenoids, and phenolics of three native fresh and sun-dried date (Phoenix dactylifera L.) varieties grown in Oman. Journal of Agric Food Chem. 53, 7592-7599.

Al-Sayyed H F, Takruri H R, Shomaf M S. (2014). The effect of date palm fruit (Phoenix dactylifera L.) on 7, 12-dimethylbenz ( $\alpha$ ) anthracene (DMBA)induced mammary cancer in rats. Res. Opin. Anim. Vet. Sciences. 4, 11-18

Al-Yahya M, Raish M, AlSaid MS, Ahmad A, Mothana RA, Al-Sohaibani M, Al-Dosari MS, Parvez MK, Rafatullah S. (2016). 'Ajwa' dates (Phoenix dactylifera L.) extract ameliorates isoproterenolinduced cardiomyopathy through downregulation of oxidative, inflammatory and apoptotic molecules in rodent model. Phytomedicine; 23(11): 1240-8.

Ansar S, Alshehri SM, Abudawood M, Hamed SS, Ahamad T. (2017). Antioxidant and hepatoprotective role of selenium against silver nanoparticles. International Journal of Nanomedicine, 12:7789-7797.

Ansari M A, Khan H M, Khan A A, Ahmad M K, Mahdi A A, Pal R, Cameotra S S. (2014). Journal of Basic Microbiol. (54): 905.

Asharani P, (2010). Investigations on the structural damage in human erythrocytes exposed to silver, gold, and platinum nanoparticles. Adv Funct Mater. 20(8):1233-42.

AshaRani PV, Low Kah Mun G, Hande MP, Valiyaveettil S (2009). "Cytotoxicity and genotoxicity of silver nanoparticles in human cells". ACS Nano. 3 (2): 279-90.

Baliga MS, Baliga BRV, Kandathil SM, Bhat HP, Vayalil PK (2011). A review of the chemistry and pharmacology of the date fruits (Phoenix dactylifera L.). Food Res Int. 44(7):1812-22.

Braydich-Stolle L, Hussain S, Schlager JJ, Hofmann MC. (2005). In vitro cytotoxicity of 
nanoparticles in mammalian germline stem cells. Toxicol Sciences. 88:412-419.

Buzea C, Pacheco II, Robbie K. (2007): Nanomaterials and nanoparticles: sources and toxicity. Biointerphases 2:17-172.

Chao C T , Krueger R R. (2007). The date palm (Phoenix Dactylifera L.): overview of biology, uses, and cultivation. Hortscience; 42, 10771082.

Chatterjee S, Dey A, Dutta R, Dey S, Acharya K. (2011). Hepatoprotective effect of the ethanolic extract of Calocybe indica on mice with $\mathrm{CCl} 4$ hepatic intoxication. International Journal of PharmTech Reseaarch. 3(4):21622168.

Chen J, Ouyang J, Kong J, Zhong W , Xing MM. (2013). Photo-cross-linked and $\mathrm{pH}-$ sensitive biodegradable micelles for doxorubicin delivery. ACS Appl Mater Interfaces.; 5(8):3108-3117).

Chen X , Schluesener HJ. (2008). Nanosilver: a nanoproduct in medical application. Toxicol Lett. 176(1):1-12.

Chuang HC, Hsiao TC, Wu CK. (2013). Allergenicity and toxicology of inhaled silver nanoparticles in allergen-provocation models. International Journal of Nanomedicine.8:4495-4506.

Culling CF, Allison RT, Barr WT. (1985). Cellular Pathology Technique. 4 Th Ed. New York: Butterworth. 642.

Dattner AM. (2003). From medical herbalism to phytotherapy in dermatology: back to the future. Dermatol Ther; 16: $106-13$

Dong Z, Surh YJ, Packer L , Cadenas E. (2009). Dietary Modulation of Cell Signaling Pathways. Boca Raton, FL, USA: CRC Press, Taylor \& Francis Group.

Dubas ST , Pimpan V. (2008). Humic acid assisted synthesis of silver nanoparticles and its application to herbicide detection, Mater. Lett. 62 (17) 2661-2663.

Eid N, Enani S, Walton G, Corona G, Costabile A , Gibson G. (2014). The impact of date palm fruits and their component polyphenols, on gut microbial ecology, bacterial metabolites and colon cancer cell proliferation. Journal of Nutration. Sciences. 3:46.

El-Badawy A, Feldhake D, Venkatapathy R. (2010). State of the Science Literature Review: Everything nano silver and more washington, DC: US Environmental Protection Agency.

El-Far AH, Shaheen HM, Abdel-Daim MM, Al Jaouni SK, Mousa SA. (2016). Date palm (Phoenix dactylifera): Protection and remedy food. Curr Tren in Nutra; 1 (29): 1-10.
El-Habibi EM, El-Komy MM, Saad HS . (2017). Protective effect of date palm extracts on cadmium-induced infertility in male rats. The Egyptian Journal of Hospital Medicine Vol.69 (4), 2181-2190

Ema M, Okuda H, Gamo M, Honda K. (2017). A review of reproductive and developmental toxicity of silver nanoparticles in laboratory animals. Reprod Toxicol 67:149-164.

Gaiser BK, Hirn S, Kermanizadeh A, Kanase N, Fytianos K,Wenk A, Haberl N, Brunelli A, Kreyling WG , Stone V .(2013). Effects of silver nanoparticles on the liver and hepatocytes in vitro. Toxicol Sciences 131:537-547.

Gopinath P, Gogoi SK, Sanpui P, Paul A, Chattopadhyay A, Ghosh SS (2010). "Signaling gene cascade in silver nanoparticle induced apoptosis". Colloids and Surfaces. B, Biointerfaces. 77 (2): 240-5.

Gupta YK, Briyal S. (2004). Animal models of cerebral ischemia for evaluation of drugs. Ind. Journal of Physiol.Pharmacol. (48):379-394.

Habib HM , Ibrahim WH. (2009). Nutritional quality evaluation of eighteen date pit varieties, Int. Journal of Food Sciences. Nutration. (60): 99111.

Han HY, Lee S K, Choi BK, Lee DR, Lee H J, Kim T W. (2019). Preventive effect of citrus aurantium peel extract on high-fat diet-induced nonalcoholic fatty liver in mice. Biol. Pharm. Bull. 42, 255-260.

Moradi-Sardareha H, Basirb H R Z, Hassanc ZM, Davoudia M, Amidid F, Paknejada M. (2018). Toxicity of silver nanoparticles on different tissues of Balb/C mice. Life Sciences 211. 8190.

Hoseinifar SH, Dadar M, Khalili M, Cerezuela R, Esteban MA. (2017). Effect of dietary supplementation of palm fruit extracts on the transcriptomes of growth, antioxidant enzyme and immune-related genes in common carp (Cyprinus carpio) fingerlings. Aquacult Res .48(7): 3684-92.

Hussain MS, Hess KL, Gearhart JM, Geiss KT, Schlager JJ. (2005). In vitro toxicity of nanoparticles in BRL 3A rat liver cells. Toxicol in Vitro 19:975983.

Jun EA, LimKM, Kim K, Bae ON, Noh JY, Chung KH, Chung JH. (2011). Silver nanoparticles enhance thrombus formation through increased platelet aggregation and procoagulant activity. Nanotoxicology 5:157-167.

Kim YS, Kim JS, Cho HS, Rha DS, Kim JM, Park JD, Choi BS, Lim R, Chang HK, Chung YH, Kwon IH, Jeong J, Han BS, Yu IJ (2008): Inhal Toxicol. Apr; 20(6):575-83 
Kim YS, Song MY, Park JD, Song KS, Ryu HR, Chung $\mathrm{YH}$, Chang HK, Lee JH, Oh KH, Kelman BJ, Hwang IK , Yu IJ. (2010): Subchronic oral toxicity of silver nanoparticles. Part Fibre Toxicol 7:1-11.

Krueger, Robert R. (2018)."Date palm genetic resource conservation, breeding, genetics, and genomics in California" (PDF). The conference exchange.

Lack, Caleb, Rousseau, Jacques. (2016). Critical thinking, science, and pseudoscience: Why we can't trust our brains. springer publishing company. 212-214.

Li H, Ying H, Hu A, Hu Y, Li D. (2017). Therapeutic effect of gypenosides on nonalcoholic steatohepatitis via regulating hepatic lipogenesis and fatty acid oxidation. Biol. Pharm. Bull. 40, 650-657.

Martínez-Gutierrez F, Thi EP, Silverman JM, de Oliveira CC, Svensson SL, Hoek AV, Sánchez EM, Reiner NE, Gaynor EC, Pryzdial ELG, Conway EM, Orrantia E, Ruiz F, Av-Gay Y, Bach H. (2012). Antibacterial activity, inflammatory response, coagulation and cytotoxicity effects of silver nanoparticles. Nanomedicine 8:328336.

Mia, Md Al-Tareq (2020). "Potentials and Safety of date palm fruit against diabetes: A Critical Review". Foods. 9 (11): 1557.

Mirza MB, Elkady Al, Al-Attar AM, Syed FQ, Mohammed FA, Hakeem KR. (2018); Induction of apoptosis and cell cycle arrest by ethyl acetate fraction of Phoenix dactylifera L. (Ajwa dates)min prostate cancer cells. Journal of Ethnopharmacol 218:35-44.

Monteiro-Riviere NA, Samberg ME, Oldenburg SJ, Riviere JE. (2013). Protein binding modulates the cellular uptake of silver nanoparticles into human cells: implications for in vitro to in vivo extrapolations? Toxicol. Lett. 220:286-293

Moradi-Sardareh H, Basir HRG, Hassan Z M, Davoudi M, Amidi F and Paknejad M. (2018). Toxicity of silver nanoparticles on different tissues of Balb/C mice. Life Sciences, 211: 81-90.

Natarjan K, Selvaraj S, Ramachandra M V. (2010). Microbial production of silver nanoparticles. Digest Journal of Nanomaterials and Biostructures. (5): 135-140.

Okonkwo CC, Agu CV, Njoku OU, Abonyi U, Apeh VO, Anaduaka EG, Iloabuchi KV, Odo CE. (2015). Hypoglycaemic and haematinic properties of ethanol leaf extract of Artocarpus heterophyllus in alloxan induced diabetic rats. Afr Journal of Tradit Complement Altern Med. 12(2):144-148

Park EJ, Bae E, Yi J, Kim Y, Choi K, Lee SH, Yoon J, LeeBC, Park K. (2010). Repeated-dose toxicity and inflammatory responses in mice by oral administration of silver nanoparticles. Environ toxicol pharmacol 30:162-168.

Park EJ, Yi J, Kim Y, Choi K, Park K (2010). "Silver nanoparticles induce cytotoxicity by a Trojanhorse type mechanism". Toxicology in Vitro. 24 (3): 872-8.

Park M, Yoo J H, Lee Y S, Lee HJ. (2019). Lonicera caerulea extract attenuates Non-alcoholic fatty liver disease in free fatty acid-induced HepG2 hepatocytes and in high fat diet-fed mice. Nutrients 11, 494.

Quang Huy T, Van Quy N, Anh-Tuan L. (2013). Silver nanoparticles: synthesis, properties, toxicology, applications and perspectives. Advances in Natural Sciences: Nanoscience and Nanotechnology. 4: 1-20.

Ragab AR, Elkablawy MA, Sheik BY, Baraka HN. (2013). Antioxidant and tissue-protective studies on Ajwa extract: dates from Al Madinah Al-Monwarah, Saudia Arabia. Journal of Environ Anal Toxicol; 3: 2161-0525.

Roozbeh J, Hashempur MH, Heydari M (2013). "Use of herbal remedies among patients undergoing hemodialysis". Iranian Journal of kidney diseases. 7 (6): 492-5.

Saafi E B, Louedi M, Elfeki A, Zakhama A, Najjar M F, Hammami M. (2011): Protective effect of date palm fruit extracts (Phoenix dactylifera L.) on dimethoate induced-oxidative stress in rat liver. Exp. Toxicol. Pathol. 63, 433-441

Salem ML, Hossain MS. (2000). Protective effect of black seed oil from Nigella sativa against murine cytomegalovirus infection. Int J ImmunopharmacolSep; 22(9):729-40.

Sharifi $M$, Bashtani $M$, Naserian AA, Farhangfar $H$. (2017). The Effect of increasing levels of date palm (Phoenix dactylifera L.) seed on theperformance, ruminal fermentation, antioxidant status and milk fatty acid profile of Saanen dairy goats. Journal of Anim Physiol Anim Nutr; 101(5): 332-341.

Sung JH, Ji JH, Park JD, Yoon JU, Kim DS, Jeon KS, Song MY, Jeong J, Han BS, Han JH, Chung YH, Chang HK, Lee JH, Cho MH, Kelman BJ, Yu IJ. (2009). Subchronic inhalation toxicity of silver nanoparticles. Toxicol Science 108:452-461.

Tiwari D K, Jin T, Behari J. (2011). Dose-dependent invivo toxicity assessment of silver nanoparticle in Wistar rats, Toxicol. Mech. Methods 21 (1) 13-24.

Tsao R (2010). Chemistry and biochemistry of dietary polyphenols. Nutrients; 2:1231-46.

Vance ME, Kuiken T, Vejerano EP, McGinnis SP, Hochella MF Jr, Rejeski D, Hull MS. (2015). Nanotechnology in the real world: Redeveloping the nanomaterial consumer 
products inventory. Beilstein Journal of Nanotechnol. 6: 1769-1780.

Wise JP, Goodale BC, Wise SS, Craig GA, Pongan AF, Walter RB. (2010): "Silver nanospheres are cytotoxic and genotoxic to fish cells". Aquatic Toxicology. 97 (1): 34-41.

Wu Y, Zhou Q. (2013). Silver nanoparticles caused oxidative damage and histological changes in Medaka (Oryzias Latipes) after 14 days of exposure. Environ Toxicol Chem 32:165-173.

Xia D L, Wang Y F, Bao N, He H, Li X d, Chen Y P. (2014). Influence of reducing agents on biosafety and biocompatibility of gold nanoparticles, Appl. Biochem.Biotechnol. 174 (7) 2458-2470.

Xin L, Wang J, Wu Y, Gue S, Tong J. (2014). Increased oxidative stress and activated heat shock proteins in human cell lianes by silver nanoparticles. Hum Exp Toxicol 34:315-323.
Yun JW, Kim SH, You JR. (2015). Comparative toxicity of silicon dioxide, silver and iron oxide nanoparticles after repeated oral administration to rats. Journal of Appl Toxicol. 35(6):681-693.

Zhang $\mathrm{Y}$, Ferguson S A, Watanabe $F$, Jones $\mathrm{Y}, \mathrm{Xu} \mathrm{Y}$, Biris A S. (2013). Silver nanoparticles decrease body weight and locomotor activity in adult male rats, Small 9 (9-10) 1715-1720.

Zhao L, Wang H, Huo K, Cui L, Zhang W, Ni H, Zhang Y, Wu Z , Chu P K. (2013). Biomaterials, (32): 5706.

Zhu X, Radovic-Moreno AF, Wu J, Langer R, Shi J. (2014). Nano Today, 9, 478. 